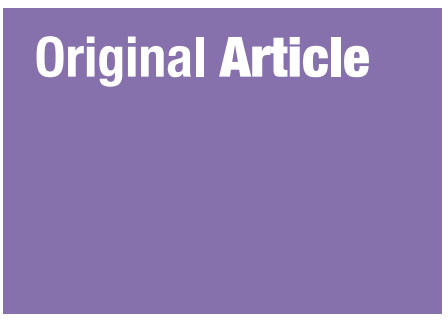

Submitted: 8 Jan 2010 Accepted: $19 \mathrm{Jul} 2010$

\section{Hyperendemicity of Onchocerciasis in Ovia Northeast Local Government Area, Edo State, Nigeria}

\author{
AKınвo Frederick Olusegun ${ }^{1,2}$, OKаKA Christopher Ehis ${ }^{2}$
}

\author{
1 Department of Pathology, University of Benin Teaching Hospital, Benin City, \\ Edo State, Nigeria
} 2 Department of Animal and Environmental Biology, University of Benin, Benin
City, Edo State, Nigeria

Background: Onchocerciasis is a chronic parasitic infection caused by the filarial nematode, Onchocerca volvulus. The objective of this study was to determine the prevalence, endemicity, and symptomatic effects of the disease in Ovia Northeast Local Government Area.

Methods: The prevalence of onchocerciasis was investigated in Ovia Northeast Local Government Area of Edo State, Nigeria, between March 2008 and June 2009 using the standard skin-snip method. A total of 2020 subjects, who had visited various primary health centres located in each community, were enlisted using randomised sampling, and the data were analysed using the Chi-squared $\left(\chi^{2}\right)$ test and logistic regression.

Results: A Of the 2020 individuals examined, 1674 (83\%) harboured microfilaria in their skin tissues. On the basis of the standardised scale for microfilaria prevalence-less than $10 \%$ is considered sporadic, $10 \%-29 \%$ is considered hypoendemic, $30 \%-59 \%$ is considered mesoendemic, and $60 \%$ and above is considered hyperendemic-the prevalence $(83 \%)$ reported in this study led to the disease being classified as hyperendemic. Females were more frequently infected than were males, and this was statistically significant $(P<0.001)$. Prevalence was also found to increase with age, and this correlation was significant $(P<\mathbf{0 . 0 0 1})$. The prevalence of the clinical features of the disease in the local government area was $\mathbf{8 7 . 5 \%}$ for leopard skin, $\mathbf{8 4 . 1 6 \%}$ for itching, and $75.42 \%$ for nodules.

Conclusion: A prevalence of $83 \%$ was observed and considered hyperendemic. Female gender and age (50 years or more) were significant risk factors that affected the prevalence of onchocerciasis. The findings demonstrated the hyperendemicity of infection and the need for urgent attention with ivermectin treatment and other control measures.

Keywords: endemics, Nigeria, Onchocerca volvulus, onchocerciasis, parasitology, prevalence, risk factors

\section{Introduction}

Onchocerciasis is a recognised public health threat caused by the filarial nematode Onchocerca vovulus. In 2001, about 18 million people are infected with the disease, of which $99 \%$ live in Africa (1). However, an estimated 37 million cases were reported in 2006, with 90 million people at risk in Africa (2). Nigeria is currently the most endemic country in the world (3). The disease has a wider distribution in Nigeria than previously believed; about 10 million cases were reported (4). Onchocerciasis in Nigeria is transmitted solely by members of the Simulium damnosum complex. They are widespread in the savannah, forestsavannah, mosaic, and forest areas of Nigeria (5). The disease is responsible for immense suffering, as it may cause severe and worrisome onchocercal skin disease, as well as disfiguring and embarrassing conditions, such as hanging groin and genital elephantiasis. The disease may also manifest with blindness in most endemic areas in Africa, especially in the rainforest belt (6). The Ovia Northeast Local Government Area (LGA) is one of the 18 LGAs in Edo State, Nigeria, that were identified through a pilot survey as having the disease, and ivermectin drug distribution to the communities by the Community-based Distribution of Ivermectin (CBDI) commenced around 1998 to reduce the pathological burden of the disease, particularly blindness. However, the true prevalence and symptomatic effects of infection have not been studied in detail among the communities in the LGA, a fact that necessitated the present study. This study investigated the prevalence, endemicity, and symptomatic effects of the infection in 40 communities of the LGA and provided data that could contribute to a programme for controlling the disease. 
Original Article | Hyperendemicity of onchocerciasis

\section{Materials and Methods}

\section{Study Area}

The study was carried out in Ovia Northeast LGA of Edo State, Nigeria. The LGA lies between latitudes $5^{\circ} 40^{\prime}$ and $7^{\circ} 40^{\prime}$ North and longitudes $5^{\circ} \mathrm{Oo}$ ' and $6^{\circ} 30^{\prime}$ East. The main river, the Ovia River, flows through all of the communities in the LGA. A total of 40 communities were involved in this study: Abumwenre, Agbenikaka, Agheanokpe, Aihuobabekun, Egbatan, Egbetta, Ewudu, Igbekhue, Iguadolor, Iguelegbon, Iguobo, Iguomo, Iguoshodinbudin, Isioho, Isiuwa, Iyekeze, Iyowa, Obazuwa/Odighi, Odiguetue, Ogbesse, Oghobahon, Okada, Okhunmwun, Okokhuo, Oluku, Ora, Orogo, Osasinwionba, Owan, Igbe, Ugbineh, Ugbogiobo, Ugbokun I, Ugbokun II, Ugbuwe, Uhen, Uhiere, Uhogua, Utekon, and Utese.

\section{Sampling technique}

The prevalence of onchocerciasis was investigated in the 40 communities located in Ovia Northeast LGA of Edo State, Nigeria, between March 2008 and June 2009 using the standard skin-snip methods. A total of 2020 subjects above the age of 5 years, who had visited various primary health centres in each community, were recruited using simple random sampling. Informed consent was obtained from all study subjects. A bloodfree skin snip was taken from individuals using a $2 \mathrm{~mm}$ bite corneo-sclera punch (E1802, Holt Storz, Germany) (6) and processed according to a previously described technique (7). Briefly, the collected snip was placed in saline solution and incubated at room temperature for 4 hours. The saline solution was then placed on a clean slide with a coverslip and viewed under a microscope. The presence of the microfilariae was taken as a positive result, while its absence was taken as a negative result. Thorough physical examinations of individual volunteers were performed by a physician. The clinical assessment of the sample population was conducted behind translucent curtains. The assessment of itching was confirmed from subjects' responses and reported as present or absent, while nodule assessment was done by inspection and palpation using hands from head to toe, with special attention to the ribcage, iliac crest, greater trochanters, knees, and scapula. In palpation, mobility and attachment to the overlying and underlining skin structures were carefully inspected to eliminate neoplastic lesions such as nodules resulting from onchocerciasis, which are usually inflammatory. The leopard skin assessment was reported as present or absent upon examination of the lower limbs for the presence of depigmentation of the skin.

\section{Statistical analysis}

Data were analysed using the Chi-square $\left(\chi^{2}\right)$ test and logistic regression with the GraphPad InStat (GraphPad Software, San Diego, CA).

\section{Results}

A total of 1674 subjects tested positive for microfilaria out of a population of 2020 subjects from whom skin snips were obtained. Table 1 shows the prevalence of clinical manifestations of onchocerciasis, with leopard skin having the highest prevalence $(87.5 \%)$, followed by itching (84.16\%), and nodules (75.42\%). Nodules had a significantly lower prevalence $(P<$ o.oo1 $)$ compared with other clinical manifestations. Females had a significantly higher prevalence of infection $(P<0.001)$ than did their male counterparts (93.1\% vs. $74.5 \%$, respectively). Generally, age affected the prevalence of onchocerciasis with individuals in the 10-19 years age group being the least affected, while individuals of more than 50 years old experienced the highest prevalence (Table 2). Communities in Ugbogiobo and Utese were heavily infected, while surrounding communities were moderately infected.

\section{Discussion}

This study recorded an overall prevalence of $83 \%$ in the Ovia Northeast LGA. This prevalence is inconsistent with previous studies (8-11). According to McMahon et al. (12), the onchocerciasis programme classifies outbreaks as sporadic, hypoendemic, mesoendemic, or hyperendemic based on the standardised microfilaria prevalence being less than $10 \%, 10 \%-$ $29 \%, 30 \%-59 \%$, and $60 \%$ and above, respectively. Therefore, Ovia Northeast LGA is classified as hyperendemic in view of the prevalence rate of $83 \%$ (12). The high prevalence rate recorded in Ovia Northeast LGA may be due to long-term infections. The majority of the subjects examined had lived in the community for more than 10 years, and they may have been continuously bitten by Simulium damnosum (vector) throughout the years. Most of the subjects were also involved in farming and hunting, which exposes them to bites from the vector. The presence of leopard skin and palpable nodules were indications of a 
Table 1: Prevalence of clinical manifestations of onchocerciasis in Ovia Northeast Local Government Area

\begin{tabular}{lccc} 
Clinical manifestation & $\begin{array}{c}\text { Patients evaluated, } \\
n\end{array}$ & $\begin{array}{c}\text { Patients affected, } \\
n(\%)\end{array}$ & $\mathbf{9 5 \%}$ CI \\
Itching & 669 & $563(84.16)$ & $0.814,0.870$ \\
\hline Nodular & 590 & $445(75.16)$ & $0.719,0.789^{\text {a }}$ \\
\hline Leopard skin & 761 & $666(87.52)$ & $0.852,0.898$ \\
\hline
\end{tabular}

${ }^{a}$ Statistical analyses were done using Chi-square $\left(\mathrm{X}^{2}\right)$ test with $P<0.001$ indicating significance in comparison with itching and leopard skin.

Table 2: The association between prevalence of onchocerciasis and various risk factors

\begin{tabular}{cccccc}
$\begin{array}{l}\text { Characteristics } \\
\text { Gender } \\
\text { Male }\end{array}$ & $\begin{array}{c}\text { Patients } \\
\text { evaluated, } \boldsymbol{n}\end{array}$ & $\begin{array}{c}\text { Patients affected, } \\
\boldsymbol{n}(\%)\end{array}$ & OR & $95 \%$ CI & P value \\
\hline Female & 1109 & $826(74.50)$ & 0.217 & $0.162,0.290^{\mathrm{a}}$ & $<0.001$ \\
\hline Age (years) & 911 & $848(93.10)$ & 4.612 & $3.453,6.160^{\mathrm{b}}$ & $<0.001$ \\
\hline$\leq 9$ & & & & & \\
\hline $10-19$ & 146 & $105(71.92)$ & 0.044 & $0.015,0.127^{\mathrm{c}}$ & $<0.001$ \\
\hline $20-29$ & 332 & $214(64.46)$ & 0.031 & $0.011,0.086^{\mathrm{c}}$ & $<0.001$ \\
\hline $30-39$ & 424 & $356(83.96)$ & 0.090 & $0.033,0.251^{\mathrm{c}}$ & $<0.001$ \\
\hline $40-49$ & 459 & $400(87.15)$ & 0.012 & $0.042,0.326^{\mathrm{c}}$ & $<0.001$ \\
\hline$\geq 50$ & 423 & $367(86.76)$ & 0.113 & $0.040,0.316^{\mathrm{c}}$ & $<0.001$ \\
\hline
\end{tabular}

Statistical analyses were done using Chi-square $\left(\mathrm{X}^{2}\right)$ test with $P<0.001$ indicating significance.

${ }^{\text {a }}$ Comparison with female patients as reference.

${ }^{\mathrm{b}}$ Comparison with male patients as reference.

${ }^{\mathrm{c}}$ Comparison with age group of 50 years and above as reference.

long-standing infection. These conditions were determined by frequent bites of the Simulium damnosum.

More females (30.4\%) than males (25.8\%) were affected by itching. The prevalence of itching increased with age and was the greatest in patients who were 20-29 years. Thereafter, there was a slight decrease in itching as the age of patients increased. It is important to note that there was a deviation in the pattern of progression of itching, in which the prevalence increased with age and then flattened out at 30 years and above $(10,13,14)$. This may be due to migration of residents in and out of the LGA in search of jobs in the urban centres or the movement of subjects from less endemic communities into the LGA for farming. Additionally, according to the CBDI, the subjects who were 30 years and older had higher ivermectin-compliance than other age groups.

Generally, the nodular prevalence recorded was significantly lower than that observed with other clinical manifestations. The skin snip (microfilaria) yields higher frequency of positive results for infection than does the observation of nodular manifestation (16). This was also observed in this study. The nodular prevalence recorded in females was higher (24.9\%) than that of males (19.7\%). This is however, different from an earlier report (17). The prevalence of nodules also increased with age, reached its peak in the 20-29 year age group, and then decreased slightly as age increased. This is different from other previous reports $(10,13,14,17)$, in which the nodular rate increased continuously with age and then remained constant for patients aged 30 years and higher. Leopard skin is a chronic onchocercal dermatitis that results from the accumulation of microfilariae that degenerate in the upper dermis and consequently lead to acute-chronic inflammation due to long-standing infection. In this study, leopard skin had the highest occurrence compared with itching and nodules. A similar observation was made by other researchers in Okpuje, Edo State, Nigeria (11). This 
Original Article | Hyperendemicity of onchocerciasis

may be attributed to the fact that most subjects with leopard skin had spent a considerable time (about 20 years and more) in these communities such that they were exposed continuously to this parasitic infection.

More females than males were infected by the disease, and this was statistically significant $(P<0.001)$. However, this observation differed from the findings of earlier reports $(11,18)$. The difference in infection rate could be explained by the domestic exposure and behavioural patterns of the inhabitants. The males are more involved in farming, and the farmlands are far away from streams that serve as Simulium breeding sites. Furthermore, the females have more contact with the stream as they fetch water for domestic use and cassava fermentation (10).

In this survey, age significantly affected the prevalence of onchocerciasis $(P<0.001)$. This finding is consistent with those of earlier reports $(8,11,17-19)$. The age-related prevalence recorded in this survey probably arose because onchocerciasis takes time to manifest.

The high prevalence of onchocerciasis, despite the administration of yearly ivermectin therapy in the LGA, may indicate resistance to ivermectin. However, this conjecture may require molecular resistance studies to confirm, especially in a country plagued by counterfeit drugs.

\section{Conclusion}

This study revealed a high prevalence of onchocerciasis (83\%); this prevalence increased with age and was higher in females. Leopard skin and itching were the most reliable clinical manifestations.

\section{Acknowledgements}

The authors would like to thank the authority of Ovia Northeast LGA, the head of the Epidemiology Unit in the council, and most especially the traditional leaders in these communities. Not to mention, special thanks to Dr L Eberechi for carrying out the physical examination on the subjects, and to the laboratory staff of the University of Benin Teaching Hospital for being supportive in allowing us to use their facilities.

\section{Authors' contributions}

Conception and design, obtaining of funding, provision of study patients, collection and assembly of the data, analysis and interpretation of the data, drafting of the article: AFO

Statistical expertise, critical revision of the article, final approval of the article: OCE

\section{Correspondence}

Dr Akinbo Frederick Olusegun

BSc, AIMLS (Histopathology), MSc, PhD (Parasitology)

Department of Pathology

University of Benin Teaching Hospital

Benin City, Nigeria

Tel: + 2348033796874

Email: fgbengang@yahoo.com

\section{References}

1. Etya'ale DE. Vision 2020: Update on onchocerciasis. Community Eye Heallth. 2001;14(38):19-21.

2. Basanez MG, Pion SDS, Churcher TS, Breitling LP, Little MP, Boussinesq M. River blindness: A success story under threat? PLoS Med. 2006;3(9):14541460.

3. Abiose A. Operational research for ivermectinbased onchocerciasis control in Nigeria. Nigerian $J$ Ophthalmol. 1993;2:32-37.

4. Report of the meeting on strategies for ivermectin distribution through the primary health care systems, Geneva, 1991. Geneva (CH): World Health Organization. Report No.: WHO/PBL/91.24 Available from: http://whqlibdoc.who.int/hq/1991/ WHO_PBL_91.24.pdf

5. Okaka CE, Emina MO, Ilevbare ZA. Human onchocerciasis and ocular defects in Egoro-Eguare, Ekpoma; a rural rainforest community in Edo State, Nigeria. Rev Parasitol. 2003;20(64):69-75.

6. Connor DH, Palmieri JR. Blackfly bite, onchocerciasis and leopard skin. Trans $R$ Soc Trop Med Hyg. 1985;79(3): $415-417$.

7. Cheesbrough M. District laboratory practice in tropical countries, Part 1. United Kingdom: Cambridge University Press; 1998.

8. Edungbola LD, Oni GA, Aiyedun BA. Babana Parasitic Disease Project. I. The study area and a preliminary assessment of onchocercal endemicity based on the prevalence of "leopard skin". Trans R Soc Trop Med Hyg. 1983;77(3):303-309.

9. Nwaorgu OC, Ohaegbula A, Onweluzo IE, Alo ALN, Agu ML, Emeh E. Results of a large scale onchocerciasis survey in Enugu State, Nigeria. $J$ Helminthol. 1994;68(2):155-159. 
10. Nmorsi OPG, Kio FE. Hypoendemicity of onchocerciasis in Odiguetue, Ovia North East Local Government Area, Edo State, Nigeria. J Med Lab Sci. 1994;4:21-25.

11. Wogu MD, Okaka CE. Prevalence and socio-economic effects of onchocerciasis in Okpuje, Owan West Local Government Area, Edo State, Nigeria. Int J Biomed Health Sci. 2008;4(3):113-119.

12. McMahon JE, Sowa SC, Maude GH, Hudson CM, Kirkwood BR. Epidemiological studies of onchocerciasis of forest villages of Sierra Leone. Trop Med Parasitol. 1988;39(3):251-259.

13. Edungbola LD, Asaolu SO, Watts SJ. The status of human onchocerciasis in the Kainji reservoir basin areas 20 years after the impoundment of the lake. Trop Geogr Med. 1986;38(3):225-232.

14. Wagbatsoma VA, Aisien MS. Ivermectin distribution coverage and the associated factors in Ekpan Village, Edo State, Nigeria. Nigerian $J$ Parasitol. 2001;22(122):157-162.

15. Brabin L. Factors affecting the differential susceptibility of males and females to onchocerciasis. Acta Leiden. 1990;59(1-2):413-426.

16. Abanobi OC, Anosike JC. Control of onchocerciasis in Nzerem-Ikpem, Nigeria: Baseline prevalence and mass distribution of ivermectin. Public Health. 2000;114(5):402-406.

17. Nwoke BEB., Shiwaku K, Takahashi H. Nigerian Onchocerciasis: Epidemiological perspective. Jpn $J$ Trop Med Hyg.1991;19(2):191-201.

18. Akinboye DO, Okwong O, Ajiteru N, Fawole O, Agbolade OM, Ayinde OO, et al. Onchocerciasis among inhabitants of Ibarapa local government community of Oyo State, Nigeria. Biomed Res. 2009;21(2):174-178.

19. Anosike JC, Onwuliri CO. Studies of filariasis in Bauchi State, Nigeria. 1. Endemicity of human onchocerciasis in Ningi Local Government Area. Ann Trop Med Parasitol. 1994;89(1):31-38. 